\title{
John Horder 1919-2012
}

Luís Pisco*

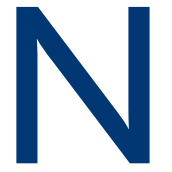

o Reino Unido, mas também a nível europeu, poucos médicos de família terão tido uma influência tão decisiva e tão marcante sobre aquilo que é hoje a actual Medicina Geral e Familiar como John Horder. É unanimemente considerado como um dos fundadores da moderna Medicina Familiar. No seu 50. ${ }^{\circ}$ aniversário a revista Pulse incluiu-o na lista dos 50 médicos de família mais influentes e mais admirados. Esta lista inclui os médicos de família que marcaram, marcam e se espera venham a marcar a Medicina de Família no Reino Unido.

Estava a terminar o seu curso de Medicina quando o National Health Service foi fundado em 1948. Esteve envolvido na criação do Royal College of General Practitioners (RCGP) em 1952, tendo sido seu presidente entre 1979 e 1982. Foi um dos fundadores do Grupo de Leeuwenhorst que ficou conhecido pela definição de Medicina Familiar e pela descrição daquilo que era o trabalho e as funções de um médico de Clínica Geral em 1974. Foi o primeiro médico de Clínica Geral inglês a ser nomeado consultor da Organização Mundial de Saúde. Ajudou a criar e a desenvolver, em vários países europeus, estruturas de apoio ao ensino da Medicina Geral e Familiar, mas a sua influência foi mais marcante na Jugoslávia e em Portugal. ${ }^{1}$

John Horder visitou Portugal várias vezes entre 1979 e 2004. Marcou profundamente o início da nossa especialidade e deixou muitos amigos e admiradores do seu trabalho e da sua personalidade. Na sua primeira visita, de 18 a 29 de Abril de 1979, foi acompanhado por Marshall Marinker, Julian Tudor Hart e John Walker para participar numa semana de debates organizados pela Escola Nacional de Saúde Pública a convite do Prof. Luís Cayolla da Mota. O grande objectivo da visita a Lisboa e da participação no seminário era dar a conhecer o Serviço Nacional de Saúde Britânico. John Horder era

*Fellow of the Royal College of General Practitioners. Professor Convidado da Faculdade de Ciências Médicas. Universidade Nova de Lisboa. na altura secretário do grupo de Leeuwenhorst (foi-o entre 1974 e 1981) que elaborou uma definição do papel do médico de família, subscrita por onze países europeus, incluindo três da Europa de leste. Deste seminário e desta visita de trabalho a Portugal resultou o Relatório Horder «O papel do médico de Clínica Geral nos cuidados de saúde primários». Este relatório abordava o papel e a organização da prática da Medicina Geral em Portugal, mas também o seu estatuto em relação à Medicina hospitalar, debatendo a criação de uma carreira atraente para jovens médicos e o seu prestígio e influência junto da profissão médica e do Governo. $\mathrm{O}$ relatório original está disponível no arquivo do RCGP, mas existe uma tradução no livro sobre os primeiros 10 anos da Associação Portuguesa de Médicos de Clínica Geral (APMCG). ${ }^{2}$ John Horder esteve novamente em Portugal no $1 .^{\circ}$ Encontro Nacional de Clínica Geral organizado pela então APMCG em Janeiro de 1984, em Évora, e onde ficou impressionado com o excelente nível organizativo e o grau de desenvolvimento da jovem carreira de Clínica Geral. À margem do Encontro teve oportunidade de pintar e tocar órgão na Sé Catedral de Évora. Em 1984 voltou a estar em Portugal, em Lisboa e Porto, e em Março de 1994 regressa ao Encontro Nacional na Póvoa do Varzim onde é homenageado pelo jornal Médico de Família. A sua última visita ao nosso país registou-se em 2004, em Vilamoura, onde participou nas celebrações dos 20 anos da APMCG e no lançamento do Livro "Da vontade» onde tem uma colaboração. ${ }^{3}$ Com 85 anos demonstra uma enorme lucidez, uma curiosidade enorme sobre o que se fazia em Portugal e como tinha evoluído a Medicina Familiar no nosso País. Com a esposa Elizabeth June, também ela médica de família, aproveita a ocasião para alugar um carro e conhecer melhor Portugal.

John Horder escreveu as suas memórias, An account of my life ${ }^{4}$ originalmente escritas para serem lidas pelos seus netos, onde considera «basicamente eu sou um artista de uma família de artistas». A música sempre foi uma parte central da sua vida, e ele sempre foi um ar- 
tista sério e talentoso. Tinha igual prazer a tocar órgão e piano. Teve oportunidade de tocar em pelo menos 30 órgãos em toda a Europa, incluindo Portugal, e em três dos mais famosos órgãos do século XVII na Holanda. Como pianista, estudou música em Paris, teve o privilégio de acompanhar cantores profissionais, mas também violinistas e violoncelistas.

John gostava de salientar a importância e o valor de ter outras preocupações e ocupações para além da Medicina, porque esta pode ser emocionalmente desgastante e pode facilmente ocupar o tempo que poderia e deveria ser gasto com a família, com os amigos ou no exercício de outras competências.

As suas outras ocupações para além da música, foram a pintura e a escrita. Qualquer uma delas já era importante muito antes de a perspectiva de uma segunda guerra mundial com a Alemanha o fazer empreender uma formação médica em detrimento da sua formação clássica em Oxford. Estas actividades vieram a revelar-se particularmente valiosas desde que se aposentou da prática médica e do ensino.

Foi um defensor incansável da aprendizagem interdisciplinar e fundou o Centro para o Progresso da Educação Inter-profissional (CAIPE) em 1987. O CAIPE foi planeado para ser uma organização destinada a apoiar e estimular uma rede nacional de indivíduos e organizações, que compartilham o propósito de promover a educação interprofissional para as profissões envolvidas na área social e da saúde. Acredita que, aprendendo juntas, diferentes profissões podem entender-se melhor umas às outras, e trabalhar melhor em conjunto. Por um curto período de tempo foi presidente da divisão local da British Medical Association. Escreveu: «Fiquei chocado com o cinismo, a preocupação com o di- nheiro, as intermináveis queixas. Vi comportamentos entre os meus colegas médicos, que eram profundamente perturbadores». ${ }^{4}$

Como médico eminente, lutou incansavelmente para o reconhecimento da Clínica Geral, como uma especialidade, contra a indiferença da academia e dos médicos da época.

O meu último encontro com John Horder foi em Londres, no Jantar de Gala no RCGP em Novembro de 2007, quando recebi o título de Honorary Fellow do RCGP. Na ocasião teve a gentileza de me oferecer, com amável dedicatória, o seu livro de memórias, publicado em Maio de 2007, e o livro com imagens de aguarelas publicado em Julho de 2007. Este inclui uma aguarela pintada em 1994 sobre Valença no Minho e uma outra, pintada em 2004, representando o Mosteiro dos Templários em Tomar.

Morreu um bom homem, um bom médico de família, um bom educador e um defensor de uma Medicina Familiar de qualidade. O seu trabalho e a sua memória permanecerão sempre connosco.

\section{REFERÊNCIAS BIBLIOGRÁFICAS}

1. Marinker M. John Horder. J r Soc Med 2004 Dec; 97 (12): 590-3.

2. Tavares J F. Os Primeiros Dez Anos da Associação Portuguesa dos Médicos de Clínica Geral, 1983-1993. Lisboa: Departamento Editorial da APMCG; 1997.

3. Horder J. Clínica Geral / Medicina Familiar: Portugal e o mundo. In: Alves MV, Ramos V, editores. Da Vontade. Lisboa: MVA Invent; 2004. p. 17-47.

4. Horder J. An account of my life. Privately printed. France; 2007.

\section{ENDEREÇO PARA CORRESPONDÊNCIA}

Rua Paulo Renato, n. 7

2500-296 Caldas da Rainha

E-mail: luispisco@mail.telepac.pt

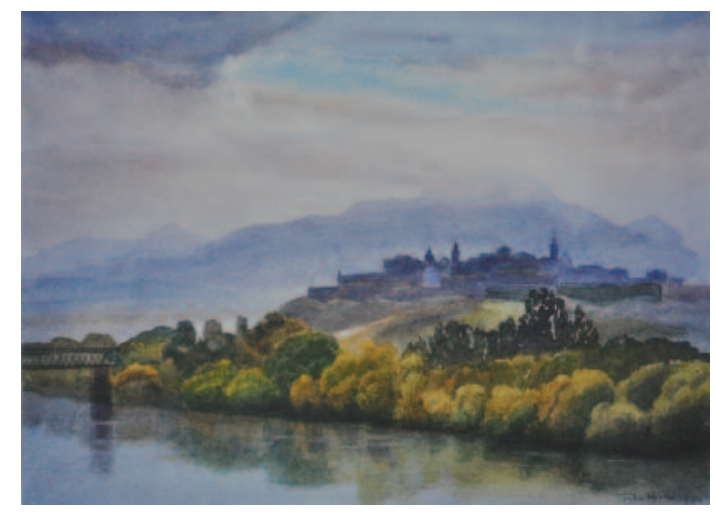

Valença do Minho John Horder 